\title{
Association Between Loss of Type IV Pilus Synthesis Ability and Phenotypic Variation in the Cucurbit Pathogenic Bacterium Acidovorax citrulli
}

\author{
Tally Rosenberg, Bolaji Babajide Salam, and Saul Burdman ${ }^{+}$ \\ Department of Plant Pathology and Microbiology, The Robert H. Smith Faculty of Agriculture, Food and Environment, \\ The Hebrew University of Jerusalem, Rehovot 76100, Israel \\ Accepted 31 December 2017.
}

\begin{abstract}
Acidovorax citrulli is the causal agent of bacterial fruit blotch of cucurbits. We have shown that functional type IV pili (T4P) are required for full virulence of this bacterium. To identify $A$. citrulli genes required for T4P activity, we screened a library of about 10,000 transposon mutants of $A$. citrulli M6 for altered T4Pmediated twitching motility. This screen led to the identification of 50 mutants impaired in twitching ability due to transposon insertions into 20 different genes. Representative mutants with disruptions in these genes were further characterized. All mutants were compromised in their virulence in seed transmission and stem inoculation assays and had reduced biofilm formation ability relative to wild-type M6. When grown on nutrient agar, most mutants produced colonies with a translucent and fuzzy appearance, in contrast to the opaque and smooth appearance of wild-type colonies. The colony morphology of these mutants was identical to that of previously reported phenotypic variants of strain M6. The exceptions were M6 mutants disrupted in genes tonB, pilT, pilW, and $p i l X$ that exhibited typical wild-type colony morphology, although lacking twitching haloes surrounding the colony. Transmission electron microscopy revealed that most mutants lacked the ability to produce T4P. The exceptions were mutants with disruptions in $\operatorname{ton} B, p i l T, p i l W$, and pilX genes that were shown to produce these appendages. These findings support the idea that colony phenotypic variation in $A$. citrulli is determined by the lack of ability to synthesize T4P but not by lack of T4P functionality.
\end{abstract}

Acidovorax citrulli is a gram-negative bacterium that causes bacterial fruit blotch (BFB) of cucurbits (Schaad et al. 2008). Under favorable conditions, characterized by high relative humidity and intermediate to high temperatures, the bacterium is able to cause seedling blight and fruit rot of a range of cucurbitaceous plants (Burdman and Walcott 2012). BFB started to gain importance after devastating outbreaks in watermelon fields in the

Current address for Bolaji Babajide Salam: Department of Postharvest Science of Fresh Produce, The Volcani Center, Agricultural Research Organization, Bet Dagan, Israel

${ }^{\dagger}$ Corresponding author: Saul Burdman; E-mail: saul.burdman@mail.huji.ac.il

Funding: This work was funded by the Israel Science Foundation grant $851 / 14$.

*The $\boldsymbol{e}$-Xtra logo stands for "electronic extra" and indicates that six supplementary figures and one supplementary table are published online.

(C) 2018 The American Phytopathological Society
Mariana Islands and in Florida in the late 1980s (Somodi et al. 1991; Wall and Santos 1988). Since then, the disease rapidly spread to many parts of the world and was reported to cause significant losses in several crops within the Cucurbitaceae family, mainly melon and watermelon (Burdman and Walcott 2012). Due to the destructive potential of the disease and the limited efficacy of BFB management strategies, $A$. citrulli is considered a serious threat to cucurbit production worldwide (Burdman and Walcott 2012).

A. citrulli strains belong to two major groups that can be clearly distinguished based on DNA fingerprinting techniques, carbon utilization profiles, fatty acid methyl ester analysis by gas chromatography-fatty acid methyl ester analysis, and host preferential association. Group I comprises strains isolated mainly from nonwatermelon hosts, while group II comprises strains isolated mainly from watermelon seedlings and fruits (Burdman et al. 2005; Walcott et al. 2000, 2004). Few genomes of A. citrulli strains are available to the scientific community. These include those of strains M6 and AAC00-1, which are considered the model group I and II strains, respectively (Eckshtain-Levi et al. 2016).

Despite the economic importance of BFB, little is known about the pathogen's virulence mechanisms. Like many other gramnegative plant pathogenic bacteria, A. citrulli relies on a functional Hrp (for hypersensitivity response and pathogenicity) type III secretion system to promote disease on susceptible plants (Bahar et al. 2010; Johnson et al. 2011). Eckshtain-Levi et al. (2014) recently showed that group I and II strains of A. citrulli can be clearly distinguished based on differences in their arsenal of type III-secreted effectors (T3Es) suggesting that, in this bacterium, differences in T3Es are critical in determining the patterns of aggressiveness on different cucurbit species.

Type IV pili (T4P) (also called type IV fimbriae) play an important role in virulence of A. citrulli (Bahar et al. 2009a). T4P are hair-like appendages found on the poles of the cell surface, where they mediate twitching motility, an efficient flagellar-independent form of bacterial surface motility (Jarrell and McBride 2008; Mattick 2002). T4P have been shown to be involved in surface adhesion and colonization, biofilm formation, genetic material transfer, and virulence (Craig et al. 2004; Nudleman and Kaiser 2004). In a previous study, we characterized pilM and pilT mutants of A. citrulli M6. In T4Pproducing bacteria, pilM encodes an inner membrane protein that is needed for T4P assembly while pilT encodes a cytoplasm or inner membrane component that mediates pilus retraction and disassembly (Burdman et al. 2011; Nudleman and Kaiser 2004). Accordingly, the A. citrulli pilM and pilT mutants were impaired in T4P assembly and function, respectively, and both mutants lacked twitching motility and had reduced biofilm 
formation ability and virulence as compared with the wild-type strain (Bahar et al. 2009a; 2010). We also showed that $A$. citrulli is able to proliferate in the xylem vessels of melon seedlings (Bahar et al. 2009a). Further, Makizumi et al. (2011) showed that $A$. citrulli was able to colonize the xylem tissue of mature squash leaves, thus supporting the vascular colonization ability of this pathogen.

Recently, we reported the natural occurrence of phenotypic variation in group I (M6) and II (7a1) strains of A. citrulli (Shrestha et al. 2013). Phenotypic variation in these strains was shown to occur at a relatively high frequency and under various conditions. Phenotypic variants (PVs) can be easily detected on nutrient agar (NA), since they produce colonies with distinguished morphology compared with those of their parental strains. In contrast to the opaque, smooth, and regular appearance of typical A. citrulli colonies, PV colonies are bigger than those of the parental strains and are translucent, fuzzy, and have irregular borders. In addition, under tested conditions, PVs do not produce T4P nor perform twitching motility and possess reduced biofilm formation and virulence abilities compared with the parental strains (Shrestha et al. 2013). All the above phenotypes are also characteristic of the A. citrulli M6 pilM mutant, suggesting an association between loss of either T4P synthesis, functionality, or both and phenotypic variation in this bacterium.

With the aim of identifying new genes involved in twitching motility in A. citrulli, we screened a Tn5 mutant library of strain M6 for impairment in this ability. We identified fifty mutants that lacked twitching motility. A plasmid rescue approach applied to all identified mutants led to the identification of twenty genes, including new mutants impaired in pilM and pilT, different from those reported by Bahar et al. (2009a; 2010). As similar as for the previously characterized pilM and pilT mutants, the new twitching mutants had reduced biofilm formation ability and compromised virulence relative to wild-type M6. A detailed characterization of mutants' abilities to produce T4P and of their colony morphology strongly support that in A. citrulli, phenotypic variation is associated with the loss of the ability to synthesize T4P but not with the loss of T4P-dependent twitching ability.

\section{RESULTS}

\section{Identification of Acidovorax citrulli M6 mutants impaired in twitching motility.}

A random mutant library in the background of Acidovorax citrulli M6 was constructed using the Epicenter EZ-Tn5 technology. The mutagenesis cassette consisted of a kanamycin resistance $\left(\mathrm{Km}^{\mathrm{R}}\right)$ marker flanked by mosaic ends, which are recognized by the transposase provided with the kit. A. citrulli M6 competent cells were transformed with the cassette and the transposase and about 10,000 colonies were screened on NA plates containing Km for altered twitching motility as compared with the wild type. Importantly, twitching motility in A. citrulli can be easily detected on NA plates by the formation of twitching haloes surrounding the bacterial colony. These haloes are clearly visible by the naked eye after $72 \mathrm{~h}$ of growth (Bahar et al. 2009a).

A total of 50 mutants that lacked twitching motility were identified. Southern blot analyses of restricted DNA from the mutants, using the $\mathrm{Km}^{\mathrm{R}}$ cassette as a probe, confirmed the effectiveness of the strategy for random mutagenesis of A. citrulli (Bahar et al. 2009a). In all mutants, the cassette appeared to be inserted only once and at varied positions in the bacterial chromosome (not shown). A plasmid rescue approach was used to identify the chromosomal location of the Tn5 cassette insertions in all mutants. Many mutants shared Tn5 cassette insertions in the same gene, leading to a total of 20 different genes (Table 1). Twenty mutants representing all identified genes were selected for further characterization. A schematic representation of the Tn5 cassette insertion in these mutants is shown in Supplementary Figure S1. To verify the impairment of twitching ability as seen by the naked eye, mutant colonies were observed under a light microscope. All mutant colonies lacked the typical wild-type twitching-mediated halo around the colony perimeter (Fig. 1).

In most T4P-producing bacteria, most genes encoding T4P biosynthetic and regulatory components are named pil and fim genes (for pilus and fimbriae, respectively) (Burdman et al. 2011; Mattick 2002). Therefore, it was not surprising that most genes detected in this study are homologs of pil/fim genes from other T4P-producing bacteria like the plant-pathogenic bacterium Xylella fastidiosa and the well-investigated bacteria in terms of T4P research, Pseudomonas aeruginosa and Neisseria spp. (Carbonnelle et al. 2006; Craig and Li 2008; Mattick 2002). They included genes pilA (pilE in Neisseria spp.), pilB, pile, pilM, pilN, pilO, pilP, pilQ, pilT, pilU, pilW (pilF in P. aeruginosa), pilX, pilY1, fimV, and fimT (Table 2).

Three mutants were disrupted in genes that belong to the same operon and encode components of chemosensory systems that regulate different types of motility in bacteria (Wadhams and Armitage 2004). The mutated genes encode proteins that are homologs of a methyl-accepting chemotaxis protein (MCP) (PilJ), a CheW-like coupling protein (named Pill in X. fastidiosa and ChpC in $P$. aeruginosa), and a CheA-like histidine kinase (PilL in $X$. fastidiosa and ChpA in $P$. aeruginosa) (Table 2). Hereafter, we refer to these genes using the names designated for $X$. fastidiosa.

An additional gene that was detected in our screen was tonB, encoding a cytoplasmic membrane proton-motive force protein. TonB proteins have been shown to be required for active transport of various substrates via the outer membrane in several gram-negative bacteria (Noinaj et al. 2010). Last, a twitchingdeficient mutant was detected in gene APS58_04405, which encodes a histidine kinase located upstream of a gene encoding a putative transcriptional regulator that belongs to the LytR/AlgR family (Table 2).

\section{Biofilm formation ability is compromised in the twitching motility mutants.}

T4P have been shown to be involved in biofilm formation of various bacterial species (Craig et al. 2004; Nudleman and Kaiser 2004). Moreover, we showed that pilM and pilT mutants of A. citrulli M6 were compromised in this ability (Bahar et al. $2009 \mathrm{a} ; 2010)$. In the present study, all mutants were significantly $(P<0.05)$ impaired in biofilm formation ability relative to wildtype M6 (Fig. 2). While most mutants showed a strong reduction in biofilm formation ability, with biofilm levels ranging from 15 to $40 \%$ of that of the wild type, few mutants (e.g., mutants in genes tonB, pilJ, pilX, and APS58_04405) showed a slighter but still significant reduction in this ability (Fig. 2).

\section{Twitching mutants have reduced virulence relative to wild-type M6.}

Bahar et al. (2009a) showed that pilM and pilT mutants of A. citrulli M6 are compromised in their virulence relative to wildtype M6. We performed stem inoculation and seed transmission assays to characterize the newly identified mutants. In stem inoculation assays, two independent experiments with similar results revealed higher percentages of wilted seedlings following inoculation with wild-type M6 in comparison with the twitching motility mutants. Data from a representative experiment is shown in Figure 3. While inoculation with strain M6 led to about 95\% of dead seedlings at 7 days after inoculation (dai), the average percentage of dead seedlings among those inoculated with the mutants ranged from approximately 15 to $50 \%$ (Fig. 3). The pilM mutant strain characterized by Bahar et al. (2009a) was also used in these experiments as an additional control (Fig. 3, strain M6-M) 
and showed a similar effect on seedling death as that observed for the newly identified pilM mutant (Fig. 3A).

In seed transmission assays, virulence was evaluated by measurement of foliage weight and stem length of seedlings emerging from inoculated seeds at 10 dai. We have shown that, in these assays, these parameters correlate negatively with disease severity (Bahar et al. 2009b). Three seed transmission assays were performed that showed similar results. Most (18 of 20) twitching motility mutants exhibited significant $(P<0.05)$ reduction in virulence (e.g., higher stem length and foliage weight values) relative to wild-type M6 (Fig. 4; Supplementary Fig. S2). With that said, two of the mutants, deficient in genes pilJ and APS58_04405, did not differ significantly from wildtype M6 in these experiments, although higher stem length and foliage weight averages were measured in plants inoculated with these mutants relative to M6-inoculated plants. Regarding the pilJ mutant, further seed transmission experiments that were performed (under different conditions, discussed below) to assess complementation of selected mutants showed that the pilJ mutant had significantly reduced virulence than the wild type. In addition,

Table 1. Strains and plasmids used in this study

\begin{tabular}{|c|c|c|c|}
\hline Strains/plasmids & Characteristics $^{\mathbf{a}}$ & $\begin{array}{l}\text { Reference } \\
\text { or source }\end{array}$ & $\begin{array}{l}\text { Locus tag in M6 } \\
\text { (and in AAC00-1) }\end{array}$ \\
\hline \multicolumn{4}{|l|}{ Acidovorax citrulli } \\
\hline M6 & $A p^{R}$, wild type, group I strain & Burdman et al. 2005 & \\
\hline M6-M & $\mathrm{Ap}^{\mathrm{R}}, \mathrm{Km}^{\mathrm{R}} ; \mathrm{Tn} 5$ mutant defective in pilM & Bahar et al. 2009a & \\
\hline M6 pilA::Tn5 & $\mathrm{Ap}^{\mathrm{R}}, \mathrm{Km}^{\mathrm{R}}, \mathrm{Tn} 5$ mutant defective in pilA & This study & N.A. ${ }^{\mathrm{c}}$ (Aave_4679) \\
\hline M6 pilB::Tn5 & $\mathrm{Ap}^{\mathrm{R}}, \mathrm{Km}^{\mathrm{R}}$, Tn5 mutant defective in pilB & This study & APS58_08770 (Aave_3680) \\
\hline M6 pile::Tn5 & $\mathrm{Ap}^{\mathrm{R}}, \mathrm{Km}^{\mathrm{R}}$, Tn 5 mutant defective in pile & This study & APS58_05050 (Aave_3550) \\
\hline M6 pilI::Tn5 & $\mathrm{Ap}^{\mathrm{R}}, \mathrm{Km}^{\mathrm{R}}, \mathrm{Tn} 5$ mutant defective in pill & This study & APS58_00910 (Aave_0903) \\
\hline M6 pilJ::Tn5 & $\mathrm{Ap}^{\mathrm{R}}, \mathrm{Km}^{\mathrm{R}}, \mathrm{Tn} 5$ mutant defective in pilJ & This study & APS58_00905 (Aave_0904) \\
\hline M6 pilL::Tn5 & $\mathrm{Ap}^{\mathrm{R}}, \mathrm{Km}^{\mathrm{R}}$, Tn5 mutant defective in pilL & This study & APS58_00900 (Aave_0905) \\
\hline M6 pilM::Tn5 & $\mathrm{Ap}^{\mathrm{R}}, \mathrm{Km}^{\mathrm{R}}, \mathrm{Tn} 5$ mutant defective in pilM & This study & APS58_00440 (Aave_0996) \\
\hline M6 pilN::Tn5 & $\mathrm{Ap}^{\mathrm{R}}, \mathrm{Km}^{\mathrm{R}}, \mathrm{Tn} 5$ mutant defective in pilN & This study & APS58_00435 (Aave_0997) \\
\hline M6 pilO::Tn5 & $\mathrm{Ap}^{\mathrm{R}}, \mathrm{Km}^{\mathrm{R}}, \mathrm{Tn} 5$ mutant defective in pilO & This study & APS58_00430 (Aave_0998) \\
\hline M6 pilP::Tn5 & $\mathrm{Ap}^{\mathrm{R}}, \mathrm{Km}^{\mathrm{R}}, \mathrm{Tn} 5$ mutant defective in pilP & This study & APS58_00425 (Aave_0999) \\
\hline M6 pilQ::Tn5 & $\mathrm{Ap}^{\mathrm{R}}, \mathrm{Km}^{\mathrm{R}}, \mathrm{Tn} 5$ mutant defective in pilQ & This study & APS58_00420 (Aave_1000) \\
\hline M6 pilT::Tn5 & $\mathrm{Ap}^{\mathrm{R}}, \mathrm{Km}^{\mathrm{R}}, \mathrm{Tn} 5$ mutant defective in pilT & This study & APS58_10505 (Aave_0637) \\
\hline M6 pilU::Tn5 & $\mathrm{Ap}^{\mathrm{R}}, \mathrm{Km}^{\mathrm{R}}, \mathrm{Tn} 5$ mutant defective in pilU & This study & APS58_10515 (Aave_0635) \\
\hline M6 pilW::Tn5 & $\mathrm{Ap}^{\mathrm{R}}, \mathrm{Km}^{\mathrm{R}}, \mathrm{Tn} 5$ mutant defective in pilW & This study & APS58_13315 (Aave_1422) \\
\hline M6 pilX::Tn5 & $\mathrm{Ap}^{\mathrm{R}}, \mathrm{Km}^{\mathrm{R}}, \mathrm{Tn} 5$ mutant defective in pilX & This study & APS58_05060 (Aave_3552) \\
\hline M6 pilY1::Tn5 & $\mathrm{Ap}^{\mathrm{R}}, \mathrm{Km}^{\mathrm{R}}, \mathrm{Tn} 5$ mutant defective in pilY1 & This study & APS58_05055 (Aave_3551) \\
\hline M6 fimT::Tn5 & $\mathrm{Ap}^{\mathrm{R}}, \mathrm{Km}^{\mathrm{R}}, \mathrm{Tn} 5$ mutant defective in fim $T$ & This study & APS58_05045 (Aave_3549) \\
\hline M6 fimV::Tn5 & $\mathrm{Ap}^{\mathrm{R}}, \mathrm{Km}^{\mathrm{R}}, \mathrm{Tn} 5$ mutant defective in fim $V$ & This study & APS58_12055 (Aave_1218) \\
\hline M6 tonB::Tn5 & $\mathrm{Ap}^{\mathrm{R}}, \mathrm{Km}^{\mathrm{R}}, \mathrm{Tn} 5$ mutant defective in tonB & This study & APS58_01195 (Aave_0842) \\
\hline M6 APS58_04405::Tn5 & $\mathrm{Ap}^{\mathrm{R}}, \mathrm{Km}^{\mathrm{R}}, \mathrm{Tn} 5$ mutant defective in APS58_04405 & This study & APS58_04405 (Aave_1948) \\
\hline M6 tonB-comp & $\begin{array}{l}\mathrm{Ap}^{\mathrm{R}}, \mathrm{Km}^{\mathrm{R}}, \mathrm{Gm}^{\mathrm{R}} \text { tonB complemented strain (carrying } \\
\text { plasmid pBBRtonB) }\end{array}$ & This study & \\
\hline M6 pilI-comp & $\begin{array}{l}\mathrm{Ap}^{\mathrm{R}}, \mathrm{Km}^{\mathrm{R}}, \mathrm{Gm}^{\mathrm{R}}, \text { pill complemented strain (carrying } \\
\text { plasmid pBBRpilI) }\end{array}$ & This study & \\
\hline M6 pilJ-comp & $\begin{array}{l}\mathrm{Ap}^{\mathrm{R}}, \mathrm{Km}^{\mathrm{R}}, \mathrm{Gm}^{\mathrm{R}}, \text { pillJ complemented strain (carrying } \\
\text { plasmid pBBRpilJ) }\end{array}$ & This study & \\
\hline M6 pilL-comp & $\begin{array}{l}\mathrm{Ap}^{\mathrm{R}}, \mathrm{Km}^{\mathrm{R}}, \mathrm{Gm}^{\mathrm{R}}, \text { pilIL complemented strain (carrying } \\
\text { plasmid pBBRpilL) }\end{array}$ & This study & \\
\hline \multicolumn{4}{|l|}{ Escherichia coli } \\
\hline BW25141 & $\begin{array}{l}\mathrm{F}^{-}, \Delta(\text { araD-araB) } 567, \Delta \text { lacZ4787(::rrnB-3 }), \Delta(\text { phoB- } \\
\quad \text { phoR } 580, \lambda^{-}, \text {galU95, } \Delta \text { uidA3 }: \text { pir }^{+}, \text {recA } 1, \\
\quad \text { endA9(del-ins) }: \because F R T, \text { rph- } 1, \Delta(\text { rhaD-rhaB }) 568, \text { hsdR514 }\end{array}$ & $\begin{array}{l}\text { Datsenko and } \\
\text { Wanner } 2000\end{array}$ & \\
\hline S17-1 $\lambda$ pir & $\begin{array}{l}\text { גlysogenic } \mathrm{S} 17-1 \text { derivative producing } \pi \text { protein for } \\
\text { replication of plasmids carrying oriR6K; recA pro } h s d R \\
\text { RP4-2-Tc::Mu-Km::Tn7 } \lambda \text { - pir }\end{array}$ & Simon et al. 1983 & \\
\hline \multicolumn{4}{|c|}{ 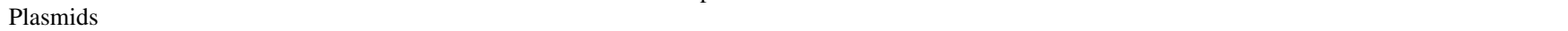 } \\
\hline $\mathrm{pUC}-4 \mathrm{~K}$ & $\begin{array}{l}\left.\text { pUC4 derivative (pMB1 ori, } \mathrm{Ap}^{\mathrm{R}}\right) \text {, containing the } \mathrm{Km}^{\mathrm{R}} \\
\text { cassette from } \mathrm{Tn} 903\end{array}$ & $\begin{array}{l}\text { Vieira and } \\
\text { Messing } 1982\end{array}$ & \\
\hline pMOxD-3 < R6K $\gamma$ ori/MCS $>$ & $\mathrm{Ap}^{\mathrm{R}} ;$ transposon construction vector & Epicenter & \\
\hline pBBR1-MCS-5 & $\mathrm{Gm}^{\mathrm{R}}$; broad host range vector & Kovach et al. 1995 & \\
\hline pBBRprom-tonB & $\begin{array}{l}\mathrm{Gm}^{\mathrm{R}} ; \mathrm{pBBR} 1-\mathrm{MCS}-5 \text { containing a } 406-\mathrm{bp} \text { fragment } \\
\text { upstream of the coding sequence of tonB gene }\end{array}$ & This study & \\
\hline pBBRprom-pil & $\begin{array}{l}\mathrm{Gm}^{\mathrm{R}} ; \text { pBBR1-MCS-5 containing a 456-bp fragment } \\
\text { upstream of the APS58_00920-APS58_0900 operon that } \\
\text { contains genes pilI, pilJ, and pilL }\end{array}$ & This study & \\
\hline pBBRtonB & $\begin{array}{l}\mathrm{Gm}^{\mathrm{R}} \text {; pBBR1-MCS-5 containing the the ton } B \text { gene with its } \\
\text { 406-bp upstream region }\end{array}$ & This study & \\
\hline pBBRpilI & $\begin{array}{l}\mathrm{Gm}^{\mathrm{R}} ; \mathrm{pBBR} 1-\mathrm{MCS}-5 \text { containing the pilI gene, the } \\
\text { upstream region of operon APS58_00920-APS58_0900 }\end{array}$ & This study & \\
\hline pBBRpilJ & $\begin{array}{l}\mathrm{Gm}^{\mathrm{R}} ; \text { pBBR } 1-\mathrm{MCS}-5 \text { containing the pilJ gene, the } \\
\text { upstream region of operon APS58_00920-APS58_0900 }\end{array}$ & This study & \\
\hline pBBRpilL & $\begin{array}{l}\mathrm{Gm}^{\mathrm{R}} ; \text { pBBR } 1-\mathrm{MCS}-5 \text { containing the pilL gene, the } \\
\text { upstream region of operon APS58_00920-APS58_0900 }\end{array}$ & This study & \\
\hline
\end{tabular}


as indicated above, both pilJ and APS58_04405 mutants induced substantially lower levels of seedling death than the wild type in stem-inoculation experiments (Fig. 3). Therefore, we are confident that all twitching-deficient mutants assessed in this study are compromised in virulence relative to the wildtype strain.
As similar as the previously characterized pilM and pilT mutants (Bahar et al. 2009a), the twitching motility mutants characterized in this study did not differ in their ability to grow in nutrient broth (NB) relative to strain M6 (not shown), thus indicating that the reduced virulence of the twitching motility mutants is not due to reduced growth ability.
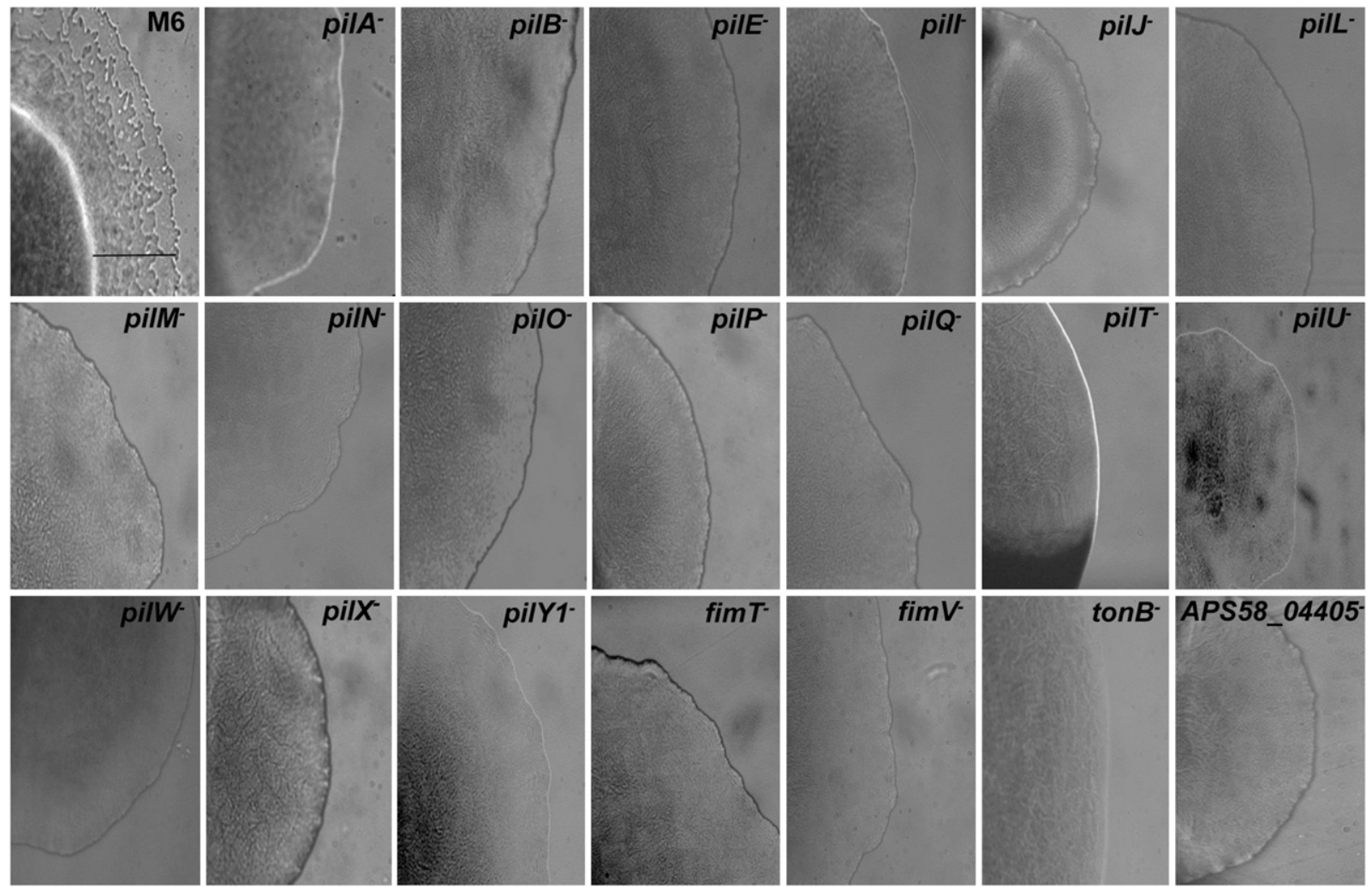

Fig. 1. The occurrence or absence of twitching motility of Acidovorax citrulli wild-type strain M6 and Tn5 mutants, respectively, as seen by light microscopy after $48 \mathrm{~h}$ of growth on nutrient agar plates at $28^{\circ} \mathrm{C}$. Typical haloes surrounding the bulk colonies (indicated by the black line in strain M6) are formed by bacteria migrating via twitching. Pictures were taken using an Axio Scope light microscope equipped with a DXM1200F digital camera.

Table 2. Genes that were shown to be required for twitching motility in Acidovorax citrulli M6 and their homologs in Pseudomonas aeruginosa and Xylella fastidiosa, based on BlastN results

\begin{tabular}{|c|c|c|c|c|}
\hline Mutated gene $^{a}$ & $\begin{array}{l}\text { Homolog in } \\
\text { P. aeruginosa }\end{array}$ & $\begin{array}{l}\text { Homolog in } \\
X \text {. fastidiosa }\end{array}$ & Gene function/product & Category $^{\mathbf{b}}$ \\
\hline pilA (2) & pilA & pilA & Major pilin & A \\
\hline pilB (3) & pilB & pilB & ATPase that mediates pilus assembly and extension & $\mathrm{C}$ \\
\hline pile (3) & pile & pile & Minor pilin & A \\
\hline pill (3) & $\operatorname{chpC}$ & pill & CheW-like coupling proteins & B \\
\hline pilJ (4) & pilJ & pilJ & Methyl accepting chemotaxis protein & B \\
\hline pilL (3) & $\operatorname{chpA}$ & pilL & CheA-like histidine kinases & B \\
\hline pilM (3) & pilM & pilM & $\mathrm{T} 4 \mathrm{P}$ assembly protein & A \\
\hline pilN (2) & pilN & pilN & Accessory protein that aids PilQ secretin activity & A \\
\hline pilO (1) & pilO & pilO & Accessory protein that aids PilQ secretin activity & A \\
\hline pilP (2) & pilP & pilP & Accessory protein in the outer membrane & A \\
\hline pilQ (4) & pilQ & pilQ & Outer membrane secretin & $\mathrm{D}$ \\
\hline pilT (3) & pilT & pilT & ATPase that mediate pilus retraction and disassembly & $\mathrm{C}$ \\
\hline pilU (1) & pilU & pilU & Protein with nucleotide binding domain & $\mathrm{C}$ \\
\hline pilW (2) & pilF & pilW & Required for T4P biogenesis/stability & A \\
\hline pilY1 (5) & pilY1 & pilY1 & Adhesin & B \\
\hline pilX (1) & pilX & pilX & Pilus-associated protein & A \\
\hline fimT (3) & fimT & fimT & Pilus assembly protein & A \\
\hline fimV (3) & fimV & $\operatorname{fim} V$ & Putative peptidoglycan-binding domain & B \\
\hline $\operatorname{ton} B(1)$ & $\operatorname{ton} B$ & $\operatorname{ton} B$ & Cytoplasmic membrane proton-motive force protein & B \\
\hline APS58_04405 (1) & $\operatorname{alg} Z$ & yesM & Histidine kinase of a two-component regulatory system & B \\
\hline
\end{tabular}

${ }^{a}$ In A. citrulli M6. The number of mutants isolated for each gene in this study is indicated in parentheses.

${ }^{\mathrm{b}}$ Categories are based on Carbonnelle et al. (2006): A, pilus assembly; B, functional maturation and regulation; C, retraction; and D, emergence on the cell surface. 
Mutants impaired in the ability to produce T4P form colonies with identical morphology to those of PVs.

We have recently characterized the phenomenon of phenotypic variation in A. citrulli. PVs of strain M6 resemble several phenotypes of a pilM mutant of this strain that does not produce T4P (Bahar et al. 2009a). Both PVs and the pilM mutant produce colonies with a translucent and fuzzy appearance, in contrast to the opaque and smooth appearance of M6 colonies (Shrestha et al. 2013) (Fig. 5). In addition, both are impaired in twitching motility and have reduced virulence and biofilm formation ability (Bahar et al. 2009a; Shrestha et al. 2013). A different mutant of strain M6, with a disruption in the pilT gene, also lacks twitching motility and possesses reduced virulence and biofilm formation ability (Bahar et al. 2009a), but its colony morphology is similar to that of wild-type M6 (Fig. 5). In contrast to the pilM mutant that does not produce T4P, the pilT not only produces them, it is hyperpiliated (Bahar et al. 2009a). These observations suggested that phenotypic variation in $A$. citrulli is determined by the lack of the ability to produce T4P rather than by injury in T4P function. To assess this hypothesis, we performed detailed observations of colonies of the new twitching-deficient mutants under a binocular and assessed, by transmission electron microscopy (TEM), whether the mutants possess the ability to produce T4P under the same growth conditions.

Most of the mutants characterized in this study showed a colony morphology type identical to those of PVs (V1 to V4) of strain M6 (Fig. 5). The exceptions were mutants with disruptions in genes tonB, pilJ, pilT, pilW, pilX, and APS58_04405, which had a colony morphology similar to that of wild-type M6 (Fig. 5). In agreement with the aforementioned hypothesis, TEM observations revealed that these six mutants, indeed, produce T4P while T4P could not be detected in the other mutants, under tested conditions (Fig. 6, showing some of the mutants; Supplementary Figs. S3 and S4).

\section{Complementation of selected mutants fully} or partially restored T4P-associated phenotypes.

Four twitching-deficient mutants, disrupted in tonB, pill, pilJ, and pilL genes, were selected for complementation. This was done by transforming the mutants with plasmid pBBR1MCS-5 carrying the corresponding genes from wild-type M6 (Table 1). As mentioned above, the tonB and pilJ mutants produce T4P but do not twitch and possess a wild type-like colony appearance (Fig. 5). In contrast, the pilI and pilL mutants do not synthesize T4P and possess a PV-like colony morphology (Fig. 5). Among the four mutants, we were able to detect restoration of twitching motility only for tonB and pilJ complemented mutants (Supplementary Fig. S5A). In terms of colony morphology, the tonB and pilJ complemented strains did not differ from the corresponding mutants and wild-type M6 (not shown). This result was expected, since all these strains synthesize T4P. Interestingly, the pill and pilL mutants carrying the complementation plasmids showed an intermediate phenotype between wild-type M6 (Fig. 5) and the corresponding mutants in terms of colony appearance; although these strains were not restored for twitching motility, their colony edges were more round-shaped in comparison with their corresponding mutants. In contrast to the pilI and pilL mutants that do not produce T4P, we were able to detect pili in the complemented strains, which could explain the aforementioned differences in colony morphology.

The complemented strains were also assessed in seed transmission assays. For these experiments, we had a different commercial soil that was less conducive to disease; therefore, $10^{8}-\mathrm{CFU} / \mathrm{ml}$ suspensions were used for seed inoculation (rather than $5 \times 10^{6}$ $\mathrm{CFU} / \mathrm{ml}$, as in previous seed transmission assays). In contrast to the first set of experiments shown in Figure 4, in these experiments, the pilJ mutant induced lower disease severity than wildtype M6, as reflected in significantly $(P<0.05)$ higher foliage weight of inoculated plants (Supplementary Fig. S6). This was also the case for the other mutants. In these assays, the averages of foliage weight recorded for plants treated with the complemented strains were lower than those inoculated with the mutants, but these differences were not statistically significant. On the other hand, the four complemented strains but not the mutants significantly $(P<0.05)$ differed from non-inoculated controls. Moreover, while foliage weight averages of plants treated with the complemented strains had higher values than those treated with wild-type M6, no significant differences were found between the latter and the $\operatorname{ton} B$ and pilJ complemented strains. Interestingly, these were the only two strains that were complemented for twitching motility.

\section{DISCUSSION}

The role of T4P in pathogenicity of animal-pathogenic bacteria has been widely investigated (Alm and Mattick 1997; Collyn et al. 2002; Craig et al. 2004; Zahavi et al. 2011). In contrast, relatively less attention has been given to the contribution of T4P



Fig. 2. Biofilm formation of Acidovorax citrulli M6 and twitching-deficient mutants. Bacteria were grown in $\mathrm{M} 9$ minimal media at $28^{\circ} \mathrm{C}$ for $48 \mathrm{~h}$ without agitation. The cultures were removed, the tubes were washed gently and biofilms formed on the tube surface were stained with $0.1 \%$ methyl violet. Stained biofilms were solubilized with $95 \%$ ethanol and biofilm formation was quantified by optical density measurements at 595 nm. Data represent averages and standard errors of one experiment out of three with similar results (three replicates per strain in each experiment). Different letters indicate significant differences $(P<0.05)$ among treatments by Tukey-Kramer and analysis of variance. 
to virulence and fitness of plant-pathogenic bacteria. With that said, in the last 15 years, several studies have contributed to the understanding of the involvement of these surface appendages in pathogenicity of some plant-pathogenic bacterial species (Burdman et al. 2011). In this regard, a clear contribution of T4P to virulence has been mainly attributed to vascular pathogenic bacteria, e.g., those bacterial pathogens that can colonize and spread through the plant xylem. These include Ralstonia solanacearum (Kang et al. 2002; Liu et al. 2001), Xylella fastidiosa (De La Fuente et al. 2007, 2008; Li et al. 2007; Meng et al. 2005), Xanthomonas oryzae pv. oryzae (Lim et al. 2008; Wang et al. 2008), Xanthomonas campestris pv. campestris (McCarthy et al. 2008), and Acidovorax citrulli (Bahar et al. 2009a). One exception is the nonvascular pathogen Pseudomonas syringae pv. tabaci, for which T4P were shown to contribute to virulence (Nguyen et al. 2012). It has been hypothesized that, in the case of vascular plantpathogenic bacteria, T4P contribute to colonization and spread in the xylem vessels by promoting attachment to and biofilm formation on the vessel surfaces as well as twitching motility in this niche (Burdman et al. 2011).
To enrich our understanding of the gene machinery used by A. citrulli to produce and regulate T4P activity and to further investigate the contribution of T4P to the virulence of this bacterium, we screened a library of A. citrulli M6 mutants for impairment in twitching motility. Sequence analyses of the mutated genes in the twitching-deficient mutants led to identification of 20 genes (Table 2). As expected, most of the detected mutants had disruptions in genes that, in other bacteria, are known to be directly connected with T4P assembly or function and are named pil or fim genes (Burdman et al. 2011; Mattick 2002). In agreement with findings in these and other bacteria, our screen revealed $A$. citrulli twitching-deficient mutants in genes that encode components of chemosensory systems that regulate motility in bacteria. In X. fastidiosa, these genes have been designated pilI, encoding a CheW-like coupling protein, pilJ, encoding a $\mathrm{MCP}$, and pilL, encoding a CheA-like histidine kinase. Similarly as in X. fastidiosa and in P. aeruginosa (Cursino et al. 2011; Fulcher et al. 2010), in A. citrulli, these genes are organized in a so-called Pil-Chp operon that controls twitching motility.
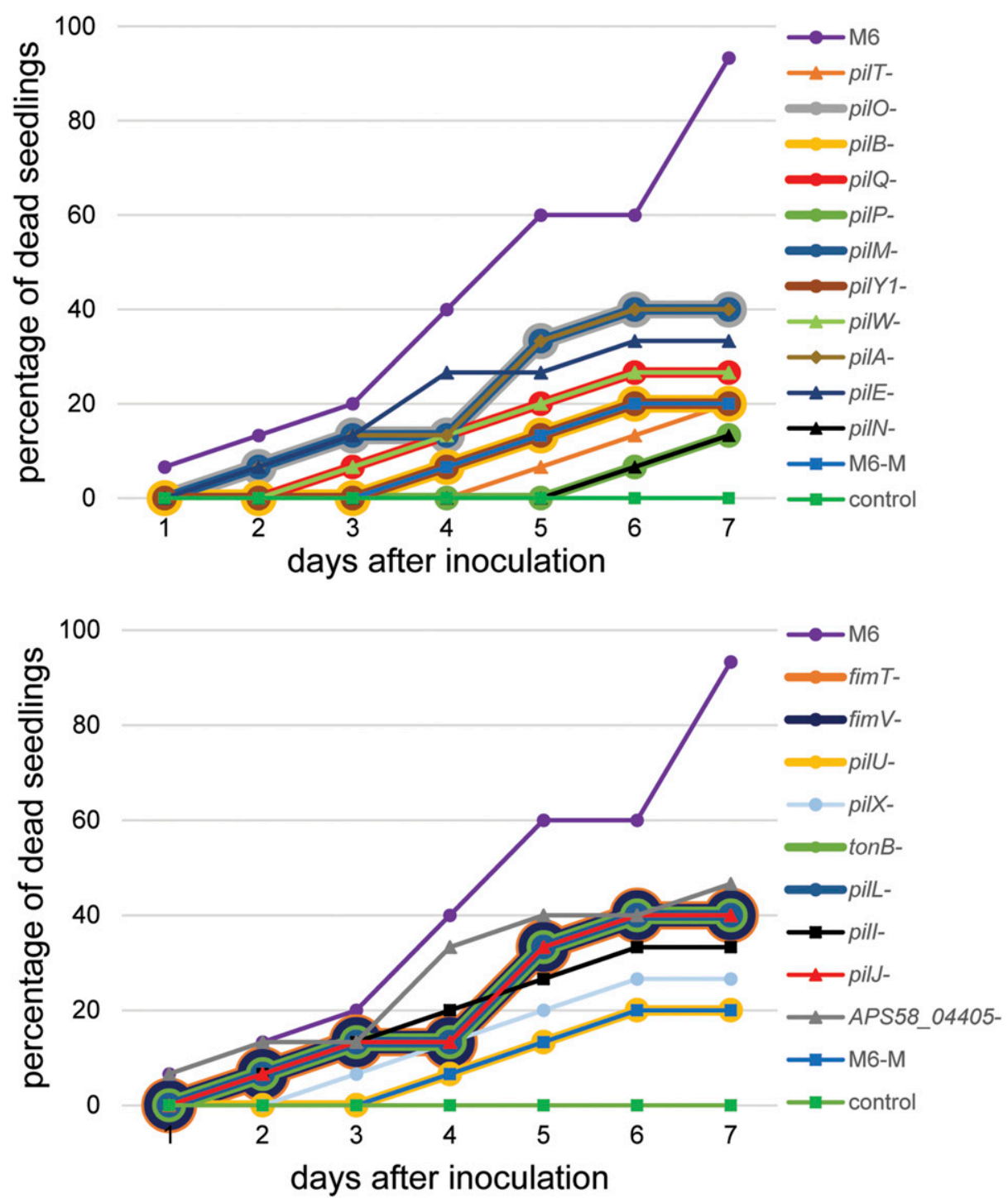

Fig. 3. Stem inoculation of melon seedlings with Acidovorax citrulli M6 and twitching-deficient mutants. Six-day-old melon cv. Ophir seedlings were inoculated by placing a 5- $\mu \mathrm{l}$ droplet containing bacteria $\left(10^{8} \mathrm{CFU} / \mathrm{ml}\right)$ at the base of the hypocotyl and passing a needle through the droplet and the stem. The seedlings were maintained in a greenhouse $\left(26\right.$ to $\left.28^{\circ} \mathrm{C}\right)$ and the percentage of dead seedlings was recorded every day. Data represent averages from one experiment (15 replicates per strain) of two with similar results. Data in both graphs are from the same experiment, but the strains were split into two graphs to allow a better visualization of each strain. For comparative purposes, wild-type strain M6, mutant M6-M (pilM mutant characterized by Bahar et al. [2009a]), and control (noninoculated seedlings) are shown in both graphs. 
According to a general model for chemotaxis, bacterial cells express transmembrane chemoreceptors that associate with CheA-like histidine kinases via CheW-coupling proteins. Ligand binding to the chemoreceptor alters the phosphorylation state of the histidine kinase, which, in turn, phosphorylates a
CheY-like response regulator. Upon phosphorylation, the response regulator interacts with the flagellum motor or with T4P to mediate swimming or twitching motility, respectively (Bertrand et al. 2010; Hazelbauer et al. 2008). In X. fastidiosa, the Pil-Chp operon was shown to be required for twitching motility. Disruption

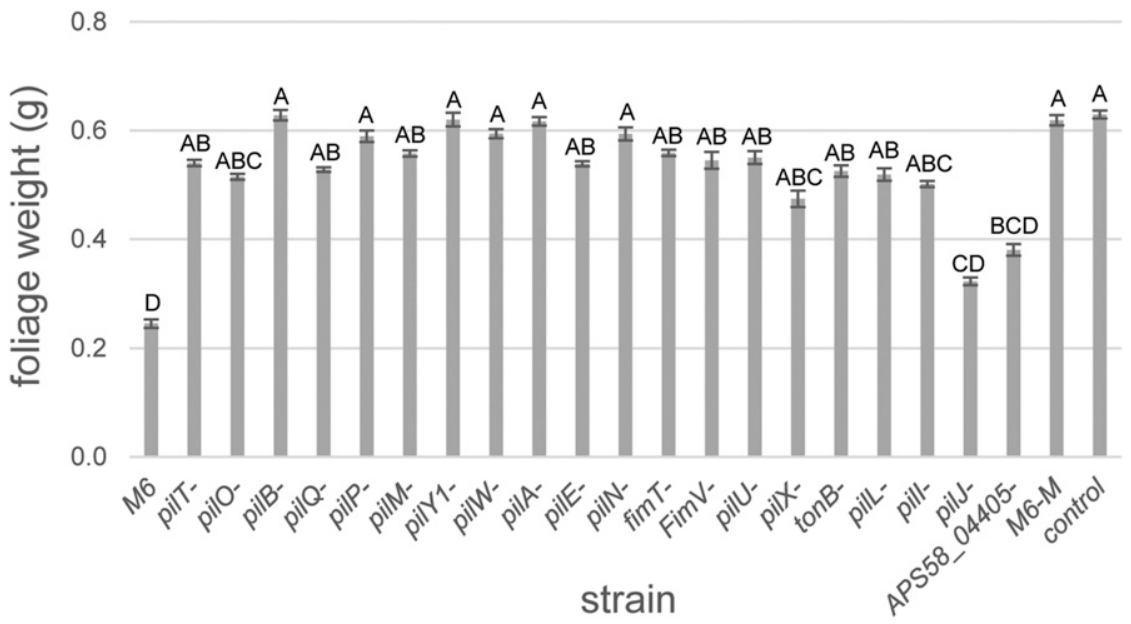

Fig. 4. Seed transmission assays of melon with Acidovorax citrulli M6 and twitching-deficient mutants. Melon cv. Ophir seeds were inoculated with bacterial strains at $5 \times 10^{6} \mathrm{CFU} / \mathrm{ml}$, sown in a peat-based commercial soil mixture and maintained in the greenhouse at 26 to $28^{\circ} \mathrm{C}$ for 10 days. At the end of this period, the weight of the above parts of the seedlings was measured, as this parameter negatively correlates with disease severity (Bahar et al. 2009b). For comparative purposes, mutant M6-M deficient in pilM (Bahar et al. 2009a) was included. Controls were plants emerging from noninoculated seeds. Data represent averages and standard errors from one experiment ( 15 replicates per strain) of three with similar results. Different letters indicate significant differences $(P<0.05)$ among treatments by Tukey-Kramer and analysis of variance.

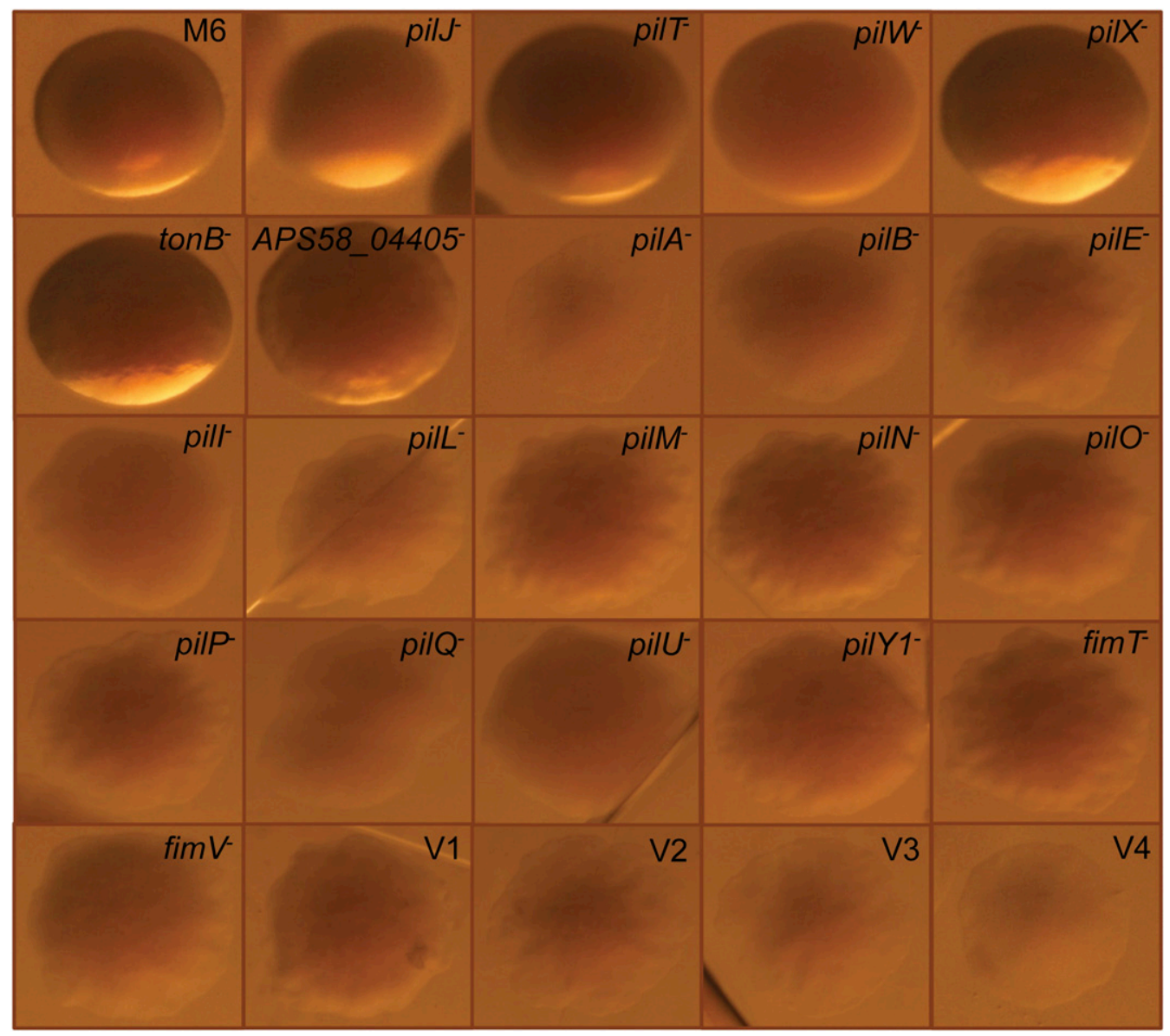

Fig. 5. Colony morphology of Acidovorax citrulli M6, twitching-deficient mutants and M6 phenotypic variants V1, V2, V3, and V4. The strains were grown on nutrient agar at $28^{\circ} \mathrm{C}$ for $48 \mathrm{~h}$. Colonies were observed with a SMZ1500 binocular equipped with a DS-Ri1 color digital camera. 
of the cheA homolog pilL led to loss of twitching motility although T4P formation was retained (Cursino et al. 2011). The authors concluded that, in this bacterium, pilL is involved in T4P function and regulation but not in T4P biogenesis. In contrast, disruption of $\operatorname{chpA}$, the pilL homolog in $P$. aeruginosa, abolished the ability of this bacterium to produce T4P (Whitchurch et al. 2004). In our study, knockouts of pilL and pilI resulted in loss of both twitching and T4P formation; however, disruption of a third gene in this operon, pilJ, led to loss of twitching motility but did not abolish T4P synthesis.

Another twitching-deficient mutant detected in our screen had a disruption in ton $B$. ton $B$ genes encode cytoplasmic membrane proton-motive force proteins that are required for active transport of several substrates across the outer membrane of gram-negative bacteria, including iron-siderophore complexes, vitamin B12, metals, sugars, and oligosaccharides (Noinaj et al. 2010; Postle and Kadner 2003; Schauer et al. 2008). Takase et al. (2000) showed that a tonB1 mutant of $P$. aeruginosa was affected in iron acquisition and host infection. Further, Abbas et al. (2007) reported that disruption of tonB1 in this bacterium also compromises biofilm formation and led to reduced twitching and swarming motilities compared with the wild-type strain. This mutant also produced lower levels of the quorum sensing (QS) signal molecule 3-oxo-C12 acyl homoserine lactone (AHL). Treatment with exogenous AHL molecules restored biofilm and motility phenotypes in the mutant, thus linking between TonB1 activity and QS (Abbas et al. 2007). Huang et al. (2004) showed that a different copy of tonB, i.e., tonB3, is also required for wild-type levels of T4P assembly and twitching motility in $P$. aeruginosa. Similar results were reported for

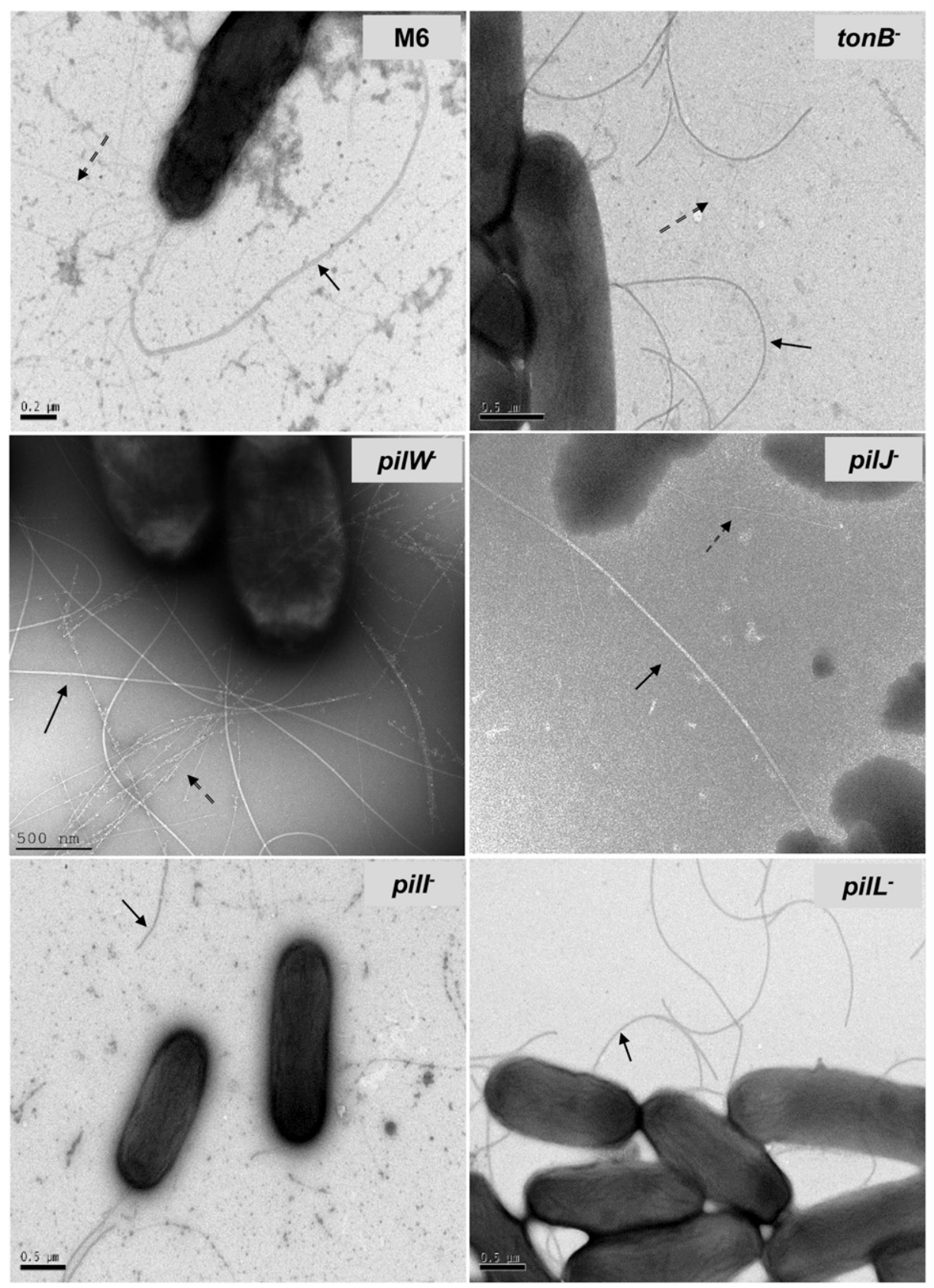

Fig. 6. Transmission electron microscopy of Acidovorax citrulli M6 and twitching-deficient mutants in genes tonB, pilW, pilJ, pill, and pilL. The strains were grown on nutrient agar at $28^{\circ} \mathrm{C}$ for $48 \mathrm{~h}$. Bacterial samples were prepared and observed in a FEI Tecnai-12 electron microscope. Solid and dashed arrows indicate polar flagellum and type IV pili (T4P), respectively. Among these strains, T4P could be detected in wild-type M6 and mutants in tonB, pilW, and pilJ but not in mutants deficient in pilI and pilL. 
$X$. fastidiosa, in which disruption of ton $B 1$ resulted in loss of twitching motility and significantly reduced biofilm formation and virulence (Cursino et al. 2009). Since the $X$. fastidiosa tonB1 mutant formed T4P, it was hypothesized that, in this bacterium, ton $B 1$ is responsible for providing the energy necessary for cellular import of molecules involved in twitching motility but not for T4P assembly (Cursino et al. 2009). In line with this background, the $A$. citrulli M6 Tn 5 mutant deficient in ton $B$ produced T4P but failed to perform twitching motility. It also had reduced levels of biofilm formation and virulence on melon seedlings, as compared with the wild-type strain. The genomes of A. citrulli M6 and AAC00-1 carry two additional ton $B$ genes, and Blast analysis revealed that the one detected in our screen is more similar to ton $B 1$ of other bacteria. It would be interesting to generate and characterize mutants deficient in the two other tonB copies of $A$. citrulli to assess whether they are also involved in T4P activity.

Our screen also identified a gene, APS58_04405, that encodes a histidine kinase protein. This gene is upstream of a $l y t R / a \lg R$ transcriptional regulator-encoding gene and is likely in the same operon. The LytR/AlgR family of transcriptional regulators commonly regulate expression of virulence factors in a variety of bacterial species (Nikolskaya and Galperin 2002). Among the best-studied transcriptional regulators of this family are Escherichia coli YehT (Kraxenberger et al. 2012), Staphylococcus aureus AgrA (Koenig et al. 2004), and Enterococcus faecalis FsrA (Del Papa and Perego 2011). The AlgR transcriptional regulator of $P$. aeruginosa also belongs to this family of transcriptional regulators and forms a two-component regulatory system with its concomitant histidine kinase AlgZ. In fact, the AlgZR two-component system is one of the global regulatory systems in $P$. aeruginosa, being important for both chronic and acute infections (Okkotsu et al. 2014). Among the phenotypes regulated by the AlgZR system in $P$. aeruginosa are alginate production (Darzins and Chakrabarty 1984) and twitching motility (Lizewski et al. 2004; Whitchurch et al. 1996). However, global transcriptome analyses support the idea that this two-component system is involved in regulation of additional traits, including QS, type III secretion, and anaerobic metabolism (Okkotsu et al. 2014). It will be interesting to further characterize the role of this two-component system in virulence and other traits of A. citrulli.

As previously shown for pilM and pilT mutants of A. citrulli M6 (Bahar et al. 2009a; 2010), all twitching-deficient mutants characterized in this study had significantly reduced biofilm formation ability and virulence on melon seedlings. Nevertheless, mutants in genes pilJ, pilX, tonB, and APS58_04405 showed biofilm formation levels that were significantly higher than the other twitching-deficient mutants (Fig. 2). Despite lacking twitching ability under tested conditions, these mutants do synthesize T4P. We speculate that, in these mutants, T4P are not fully functional in order to perform twitching motility, but their presence still contributes to some level of biofilm formation, probably because of the adhesive characteristics of T4P. In this regard, the exceptions were the pilW and pilT mutants that also produce T4P but possess biofilm formation levels that are comparable to those of the T4P synthesisdeficient mutants (Fig. 2). pilW genes (named pilF in $P$. aeruginosa and $t g l$ in Myxococcus xanthis) encode outer membrane proteins that assist in the assembly of the outer membrane secretin PilQ (Carbonnelle et al. 2005; Koo et al. 2008; Rodriguez-Soto and Kaiser 1997). The pilWorthologs in P. aeruginosa and M. xanthis are required for T4P formation (Rodriguez-Soto and Kaiser 1997; Watson et al. 1996). In contrast, in Neisseria meningitidis, pilW contributes to stability and functionality of the pilus fibers but is not required for their assembly (Carbonnelle et al. 2005). It seems that, in A. citrulli, disruption of pilW does not abolish pilus assembly but renders nonstable pili that are not able to contribute to the levels of biofilm formation seen in the T4P-producing mutants deficient in pilJ, pilX, tonB, or APS58_04405. Regarding pilT, we have previously shown that disruption of this gene in A. citrulli leads to hyperpiliation (Bahar et al. 2009a). Consequently, probably because of the adhesive character of T4P, in liquid suspension or media, pilT mutants form aggregates that sink to the bottom (Bahar et al. 2009a), thus explaining the low levels of biofilm formation of pilT mutants under tested conditions.

Importantly, we cannot exclude the possibility that some of the phenotypes observed for some of the mutants characterized in this study are due to polar effects. Here, we assessed complementation of mutants disrupted in genes tonB, pilI, pilJ, and pilL. While complementation vectors restored twitching motility in the tonB and pilJ mutants, we could not detect such phenotype restoration in the pilI and pilL mutants. With that said, in contrast to the pilI and pill mutants that lack T4P synthesis ability, their corresponding complemented strains did produce T4P. These results as well as results from seed transmission assays suggest that the complementation vectors partially restored T4P deficiency in the four mutants. Partial phenotype restoration could be due to either nonoptimal expression of the complemented genes, to unsolved polar effects, or both, particularly in the cases of pilI, pilJ, and pilL that are part of an operon.

We have recently reported the phenomenon of phenotypic variation in $A$. citrulli (Shrestha et al. 2013). PVs of A. citrulli M6 were shown to possess similar phenotypes of those of a M6 pilM mutant, including loss of the ability to produce T4P and perform twitching, reduced biofilm formation and virulence abilities, and formation of clearly distinguished colonies relative to wild-type M6 (Shrestha et al. 2013). The association between phase or phenotypic variation and loss of T4P synthesis has been widely studied in human and animal pathogens. Since modulation of piliation may represent a mechanism to evade host immune response, the molecular basis of phase variation involving loss of $\mathrm{T} 4 \mathrm{P}$ is of considerable interest (Mattick 2002). In Neisseria gonorrheae and Moraxella bovis, phenotypic variation typically involves genomic recombination or mutagenic events that directly affect pilin synthesis or assembly (Marrs et al. 1988; Segal et al. 1985). In Eikenella corrodens, it has been suggested that posttranslational events are involved in alteration of pilin export and assembly, leading to phenotypic variation (Villar et al. 1999). In the present study, identification and characterization of 20 A. citrulli M6 mutants deficient in twitching motility allowed us to conclude that, in this bacterium, phenotypic variation is connected to the loss of the ability to synthesize T4P but not to their function in terms of twitching motility. While mutants that lacked the ability to produce T4P showed colony morphology typical of naturally occurring PVs of strain M6, mutants deficient in twitching motility but that retained the ability to produce T4P (e.g., tonB, pilJ, pilT, pilW, pilX, and APS58_04405) had a colony morphology that was identical to the wild type (Fig. 5).

DNA-fingerprinting analyses by pulse-field gel electrophoresis and repetitive polymerase chain reaction (PCR) suggested that no major genomic rearrangements are involved in phenotypic variation of $A$. citrulli M6 (Shrestha et al. 2013). We have recently sequenced four PVs of strain M6, V1 to V4, by Illumina MiSeq. Comparative sequence analyses revealed many putative genetic differences in terms of nucleotide substitutions and insertions or deletions between the PVs and the parental strain (T. Rosenberg and S. Burdman unpublished results). However, we cannot exclude the possibility that many of the differences found in these analyses are, in fact, artifacts due to sequencing mistakes or errors in assembly. Importantly, we 
were not able to detect mutations shared by the four variants and no mutations were detected in coding as well as promoter regions of known T4P-related genes. Based on these results and on the high frequency of occurrence of phenotypic variation in A. citrulli M6 (approximately $10^{-3}$ under a variety of conditions [Shrestha et al. 2013]), we hypothesize that disruption of any gene required for pilin synthesis or T4P assembly results in phenotypic variation in this bacterium.

Due to the importance of BFB and the high frequency of phenotypic variation in $A$. citrulli, the implication of this phenomenon to bacterial fitness is of considerable interest. We have shown that PVs of A. citrulli M6 are less virulent than the parental strain but possess higher swimming motility and produce colonies with significantly higher bacterial numbers than the parental strain (Shrestha et al. 2013). However, more investigation is needed to assess the implication of these findings to the interaction of the pathogen with its hosts and to its fitness in different environments.

\section{MATERIALS AND METHODS}

\section{Bacterial strains and plasmids.}

The bacterial strains and plasmids used in this study are listed in Table 1. Unless stated otherwise, Acidovorax citrulli strains were grown in NB (Difco Laboratories, Detroit) or NA (NB containing $15 \mathrm{~g}$ of agar per liter) at $28^{\circ} \mathrm{C}$ for $48 \mathrm{~h}$. For biofilm experiments, A. citrulli strains were grown in M9 minimal medium (Sambrook et al. 1989) with $0.3 \%$ casamino acid and $20 \%$ glucose. For inoculation experiments, A. citrulli strains were grown on NA for $48 \mathrm{~h}$, were resuspended from plates with sterilized distilled water (SDW), were adjusted to an optical density at $600 \mathrm{~nm}\left(\mathrm{OD}_{600}\right)$ of 0.2 (about $\left.10^{8} \mathrm{CFU} / \mathrm{ml}\right)$ using a Helios Gamma spectrophotometer (Thermo Electron Corp., Rochester, $\mathrm{NY}$ ), and were then diluted (or not) to the desired concentration (discussed below). Inoculum concentrations were verified by dilution plating. E. coli strains were cultured in Luria-Bertani (LB) (Difco Laboratories) at $37^{\circ} \mathrm{C}$. Antibiotics were added to $A$. citrulli and $E$. coli cultures according to the resistances described in Table 1, i.e., ampicillin, $100 \mu \mathrm{g} / \mathrm{ml}$ and $\mathrm{Km}, 50 \mu \mathrm{g} / \mathrm{ml}$.

\section{Molecular manipulations.}

Routine molecular manipulations and cloning were carried out using standard procedures (Sambrook et al. 1989). T4 DNA ligase and restriction enzymes were purchased from Fermentas (Burlington, Canada). Kits for plasmid and PCR product extraction and purification were purchased from BioNeer Corporation (Daejeon, Republic of Korea). Genomic DNA from A. citrulli strains was prepared using the GenElute bacterial genomic DNA kit (Sigma-Aldrich, Saint Louis). Southern blot hybridization was performed using the ECL direct nucleic acid labeling and detection system from Amersham Biosciences (Buckinghamshire, U.K.), according to the manufacturer's instructions. DNA sequencing was performed with the BigDye terminator cycle sequencing kit from Applied Biosystem, Inc. (Foster City, CA, U.S.A.), using an automated sequencer at Hy Laboratories (Rehovot, Israel). PCR primers were purchased from Hy Laboratories and PCR reactions were performed, with the Readymix Red Taq PCR reactive mix (Sigma-Aldrich) or with Phusion high-fidelity DNA polymerase (New England Biolabs, Beverly, MA, U.S.A.), using an Eppendorf (Hamburg, Germany) thermal cycler.

\section{Construction of a random transposon library of $A$. citrulli M6 and screening for impaired twitching motility.}

A random transposon library formed by about 10,000 mutants was generated on the background of A. citrulli M6, using the EZ-Tn5 kit (Epicentre, Madison, WI, U.S.A.), as described
(Bahar et al. 2009a). Briefly, the $\mathrm{Km}^{\mathrm{R}}$ gene from plasmid pUC$4 \mathrm{~K}$ was cloned into the multiple cloning site of the transposon construction vector pMOD-3 $<$ R6K $\gamma$ ori/MCS $>$ following restriction of both with BamHI. The resulting vector was digested with $P v u I I$ to excise the mutagenesis cassette, which included

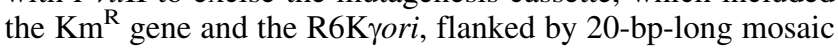
ends on both sides. The cassette, along with the EZ-Tn5 transposase were electroporated into A. citrulli M6 electrocompetent cells using an Eppendorf 2510 electroporator, and putative transformants were selected on NA with $\mathrm{Km}$ as described (Bahar et al. 2009a). The putative Tn5 mutants were replicated onto new NA and Km plates and were stored in $20 \%$ glycerol at $-80^{\circ} \mathrm{C}$. Mutants deficient in twitching motility were directly screened on the NA and $\mathrm{Km}$ selection plates and were verified by microscope observations of the colonies, using an Axio Scope light microscope (Carl Zeiss, Jena, Germany) equipped with a DXM1200F digital camera (Nikon, Tokyo). The selected mutants were tested by Southern blot to verify that they carry a single insertion of the Tn5 cassette. A plasmid rescue procedure was used to identify the mutated region of each mutant as described (Bahar et al. 2009a). Briefly, genomic DNA was purified and digested with restriction enzymes that do not cut inside the mutagenesis cassette, keeping the $\mathrm{Km}^{\mathrm{R}}$ gene and the R6K rori fragment intact. Digestion products were then autoligated and electroporated into electrocompetent $E$. coli BW25141 cells. $\mathrm{Km}^{\mathrm{R}}$ transformants were isolated in $\mathrm{LB}$ and $\mathrm{Km}$ plates and were used for plasmid preparation and sequencing of the flanking regions surrounding the insertion site of the mutagenesis cassette with primers $\mathrm{pMOD}<\mathrm{MCS}>\mathrm{F}\left(5^{\prime}-\right.$ GCCAACGACTACGCACTAGCCAAC- $\left.3^{\prime}\right)$ and pMOD $<\mathrm{MCS}>$ R (5'-GAGCCAATATGCGAGAACACCCGAGAA-3').

\section{Construction of complemented strains.}

To generate complemented strains for mutants disrupted in tonB, pilI, pilJ, and pilL genes, suitable plasmids were constructed using pBBR1-MCS-5 by the restriction free (RF) cloning procedure (Restriction Free Cloning database). All primers were designed according to the A. citrulli M6 genome (GenBank NZ_LKUW00000000.1) and are detailed in Supplementary Table S1. Briefly, the tonB gene was cloned with its promoter region (406 bp) and each of the genes pill, pilJ, and pilL were cloned with a region (456 bp) containing the promoter of the APS58_00920-APS58_0900 operon, in which these genes are located. All RF-PCR amplifications were done using high-fidelity DNA polymerase Phusion (New England Biolabs). The resulting plasmids were transformed into $E$. coli S-17-1 $\lambda$ pir by electroporation as described (Bahar et al. 2009a). Plasmids were extracted using the BioNeer AccuPrep plasmid mini extraction kit and were sent for sequencing at $\mathrm{Hy}$ Laboratories Ltd., before conjugation with the corresponding M6 mutant as described (Bahar et al. 2009a). The transformants were selected by gentamicin resistance and were used for phenotypic characterization.

\section{Biofilm formation assays.}

Biofilm assays were performed using 14-ml polystyrene round-bottom tubes (Thermo Fisher Scientific, Waltham, MA, U.S.A.), using a protocol modified from O'Toole et al. (1999). Briefly, each tube was filled with $1 \mathrm{ml}$ of M9 minimal medium as described above and was then inoculated with $10 \mu \mathrm{l}$ of a 3-ml NB overnight bacterial culture $\left(\mathrm{OD}_{600 \mathrm{~nm}}=0.2\right)$. The tubes were incubated at $28^{\circ} \mathrm{C}$ for $48 \mathrm{~h}$ without agitation. Then cultures were poured out and the tubes were rinsed with SDW. Following fixation at $80^{\circ} \mathrm{C}$ for $20 \mathrm{~min}$, biofilms formed on the surfaces were stained with $0.1 \%$ methyl violet for $30 \mathrm{~min}$. Tubes were rinsed with distilled water and were analyzed quantitatively by solubilizing the stained biofilms with $95 \%$ ethanol for $2 \mathrm{~h}$ and measuring 
the $\mathrm{OD}_{595}$ of the stained suspension in a Helios Gamma spectrophotometer. This experiment was carried out three times with three replicates per strain in each experiment.

\section{Virulence assays.}

Stem-inoculation experiments were performed as described by Bahar et al. (2011) with few modifications. Briefly, melon (Cucumis melo) cv. Ophir (Zeraim Gedera, Kibbutz Revadim, Israel) seedlings were grown individually in $11-\mathrm{cm}$ diameter poly pots (Tefen, Nahsholim, Israel) containing a peat-based commercial soil mixture (Shacham Givat Ada, Israel), in a greenhouse at 26 to $28^{\circ} \mathrm{C}$. At 6 days after sowing, each seedling was inoculated by placing a $5-\mu 1$ droplet from a $10^{8}-\mathrm{CFU} / \mathrm{ml}$ bacterial suspension at the base of the hypocotyl (about $1 \mathrm{~cm}$ from the soil). Then, a 25gauge needle was passed through the droplet and the stem and immediately taken out. The droplets were immediately removed, and seedlings were kept in the greenhouse. The percentage of dead seedlings was evaluated every day until 7 dai. This experiment was carried out twice and 15 replicates per mutant or wild-type strain were used in each experiment.

Seed transmission assays were performed as described by Bahar et al. (2009b) with minor modifications. Melon cv. Ophir seeds were placed inside a 50-ml Falcon tube containing $10 \mathrm{ml}$ of bacterial suspensions at $5 \times 10^{6} \mathrm{CFU} / \mathrm{ml}$. Seeds were incubated at room temperature with gentle agitation for $2 \mathrm{~h}$. The bacterial suspensions were then discarded, and the seeds were washed briefly with SDW and were dried under a laminar flow hood. Seeds were then sown individually in 11-cm diameter poly pots (Tefen), containing a peat-based commercial soil mixture (Shacham Givat Ada), in a greenhouse $\left(26\right.$ to $\left.28^{\circ} \mathrm{C}\right)$. At 10 dai, the fresh weight of seedling above parts (foliage) and the length of the stems were measured. These parameters were shown to negatively correlate with disease severity in seed transmission assays in the A. citrullimelon pathosystem (Bahar et al. 2009b). This experiment was carried out three times and 15 replicates per mutant or wild-type strain were used in each experiment. Further, two additional seed transmission assays were carried out to test tonB, pilI, pilJ, and pilL complemented strains in comparison with their corresponding mutants and wild-type M6. For these experiments, we had a different commercial soil (Garden Mix; Peka, Rehovot, Israel) that was less conducive to disease, thus $10^{8}-\mathrm{CFU} / \mathrm{ml}$ suspensions were used for seed inoculation. The other conditions were as described above. Two experiments, each with 15 replicates per treatment, were carried out.

\section{Binocular and TEM observations.}

Morphological observations of bacterial colonies were done using a SMZ1500 stereomicroscope (binocular) equipped with a DS-Ri1 color digital camera (both from Nikon). Transmission electron microscopy (TEM) was used to visualize T4P in wildtype and twitching-deficient mutant strains of A. citrulli. Samples from 48 -h-old, NA-grown colonies were prepared. A 5- $\mu$ l sterile water drop was dropped on a selected colony for 2 min, then, a 300-mesh carbon grid was placed on top of each colony for $30 \mathrm{~s}$ and the grid was negatively stained in a $1 \%$ uranyl drop for $10 \mathrm{~s}$. The grids were examined using a FEI Tecnai-12 electron microscope (FEI, Eindhoven, The Netherlands) equipped with a F224HD 2k $\times$ 2k CCD camera (TVIPS, Gauting, Germany).

\section{Statistical analysis.}

All quantitative assays were analyzed using the Tukey-Kramer test for mean comparison in conjunction with analysis of variance using JMP software (SAS Institute Inc., Cary, NC, U.S.A.).

\section{ACKNOWLEDGMENTS}

We thank N. Elad from the Electron Microscopy Unit of the Weizmann Institute of Science for his helpful assistance with TEM imaging.

\section{LITERATURE CITED}

Abbas, A., Adams, C., Scully, N., Glennon, J., and O'Gara, F. 2007. A role for TonB1 in biofilm formation and quorum sensing in Pseudomonas aeruginosa. FEMS Microbiol. Lett. 274:269-278.

Alm, R. A., and Mattick, J. S. 1997. Genes involved in the biogenesis and function of type-4 fimbriae in Pseudomonas aeruginosa. Gene 192:89-98.

Bahar, O., and Burdman, S. 2010. Bacterial fruit blotch: A threat to the cucurbit industry. Isr. J. Plant Sci. 58:19-31.

Bahar, O., De La Fuente, L., and Burdman, S. 2010. Assessing adhesion, biofilm formation and motility of Acidovorax citrulli using microfluidic flow chambers. FEMS Microbiol. Lett. 312:33-39.

Bahar, O., Goffer, T., and Burdman, S. 2009a. Type IV pili are required for virulence, twitching motility, and biofilm formation of acidovorax avenae subsp. citrulli. Mol. Plant-Microbe Interact 22:909-920.

Bahar, O., Kritzman, G., and Burdman, S. 2009b. Bacterial fruit blotch of melon: Screens for disease tolerance and role of seed transmission in pathogenicity. Eur. J. Plant Pathol. 123:71-83.

Bahar, O., Levi, N., and Burdman, S. 2011. The cucurbit pathogenic bacterium Acidovorax citrulli requires a polar flagellum for full virulence before and after host-tissue penetration. Mol. Plant-Microbe Interact. 24:1040-1050.

Bertrand, J. J., West, J. T., and Engel, J. N. 2010. Genetic analysis of the regulation of type IV pilus function by the Chp chemosensory system of Pseudomonas aeruginosa. J. Bacteriol. 192:994-1010.

Burdman, S., Bahar, O., Parker, J. K., and De La Fuente, L. 2011. Involvement of type IV pili in pathogenicity of plant pathogenic bacteria. Genes (Basel) 2:706-735.

Burdman, S., Kots, N., Kritzman, G., and Kopelowitz, J. 2005. Molecular, physiological, and host-range characterization of Acidovorax avenae subsp. citrulli isolates from watermelon and melon in Israel. Plant Dis. 89:1339-1347.

Burdman, S., and Walcott, R. 2012. Acidovorax citrulli: Generating basic and applied knowledge to tackle a global threat to the cucurbit industry. Mol. Plant Pathol. 13:805-815.

Carbonnelle, E., Helaine, S., Nassif, X., and Pelicic, V. 2006. A systematic genetic analysis in Neisseria meningitidis defines the Pil proteins required for assembly, functionality, stabilization and export of type IV pili. Mol. Microbiol. 61:1510-1522.

Carbonnelle, E., Hélaine, S., Prouvensier, L., Nassif, X., and Pelicic, V. 2005. Type IV pilus biogenesis in Neisseria meningitidis: PilW is involved in a step occurring after pilus assembly, essential for fibre stability and function. Mol. Microbiol. 55:54-64.

Collyn, F., Léty, M. A., Nair, S., Escuyer, V., Ben Younes, A., Simonet, M., and Marceau, M. 2002. Yersinia pseudotuberculosis harbors a type IV pilus gene cluster that contributes to pathogenicity. Infect. Immun. 70:6196-6205.

Craig, L., and Li, J. 2008. Type IV pili: Paradoxes in form and function. Curr. Opin. Struct. Biol. 18:267-277.

Craig, L., Pique, M. E., and Tainer, J. A. 2004. Type IV pilus structure and bacterial pathogenicity. Nat. Rev. Microbiol. 2:363-378.

Cursino, L., Galvani, C. D., Athinuwat, D., Zaini, P. A., Li, Y., De La Fuente, L., Hoch, H. C., Burr, T. J., and Mowery, P. 2011. Identification of an operon, Pil-Chp, that controls twitching motility and virulence in Xylella fastidiosa. Mol. Plant-Microbe Interact 24:1198-1206.

Cursino, L., Li, Y., Zaini, P. A., De La Fuente, L., Hoch, H. C., and Burr, T. J. 2009. Twitching motility and biofilm formation are associated with tonB1 in Xylella fastidiosa. FEMS Microbiol. Lett. 299:193-199.

Darzins, A., and Chakrabarty, A. M. 1984. Cloning of genes controlling alginate biosynthesis from a mucoid cystic fibrosis isolate of Pseudomonas aeruginosa. J. Bacteriol. 159:9-18.

Datsenko, K. A., and Wanner, B. L. 2000. One-step inactivation of chromosomal genes in Escherichia coli K-12 using PCR products. Proc. Natl. Acad. Sci. U.S.A. 97:6640-6645.

De La Fuente, L., Burr, T. J., and Hoch, H. C. 2007. Mutations in type I and type IV pilus biosynthetic genes affect twitching motility rates in Xylella fastidiosa. J. Bacteriol. 189:7507-7510.

De La Fuente, L., Burr, T. J., and Hoch, H. C. 2008. Autoaggregation of Xylella fastidiosa cells is influenced by type I and type IV pili. Appl. Environ. Microbiol. 74:5579-5582.

Del Papa, M. F., and Perego, M. 2011. Enterococcus faecalis virulence regulator FsrA binding to target promoters. J. Bacteriol. 193:1527-1532.

Eckshtain-Levi, N., Munitz, T., Živanović, M., Traore, S. M., Spröer, C., Zhao, B., Welbaum, G., Walcott, R., Sikorski, J., and Burdman, S. 2014 Comparative analysis of type III secreted effector genes reflects divergence of Acidovorax citrulli strains into three distinct lineages. Phytopathology 104:1152-1162.

Eckshtain-Levi, N., Shkedy, D., Gershovits, M., Da Silva, G. M., Tamir-Ariel, D., Walcott, R., Pupko, T., and Burdman, S. 2016. Insights from the genome 
sequence of Acidovorax citrulli M6, a group I strain of the causal agent of bacterial fruit blotch of cucurbits. Front. Microbiol. 7:430.

Fulcher, N. B., Holliday, P. M., Klem, E., Cann, M. J., and Wolfgang, M. C. 2010. The Pseudomonas aeruginosa Chp chemosensory system regulates intracellular cAMP levels by modulating adenylate cyclase activity. Mol. Microbiol. 76:889-904.

Hazelbauer, G. L., Falke, J. J., and Parkinson, J. S. 2008. Bacterial chemoreceptors: High-performance signaling in networked arrays. Trends Biochem. Sci. 33:9-19.

Huang, B., Ru, K., Yuan, Z., Whitchurch, C. B., and Mattick, J. S. 2004. tonB3 is required for normal twitching motility and extracellular assembly of type IV pili. J. Bacteriol. 186:4387-4389.

Jarrell, K. F., and McBride, M. J. 2008. The surprisingly diverse ways that prokaryotes move. Nat. Rev. Microbiol. 6:466-476.

Johnson, K. L., Minsavage, G. V., Le, T., Jones, J. B., and Walcott, R. R. 2011 Efficacy of a nonpathogenic Acidovorax citrulli strain as a biocontrol seed treatment for bacterial fruit blotch of cucurbits. Plant Dis. 95:697-704.

Kang, Y., Liu, H., Genin, S., Schell, M. A., and Denny, T. P. 2002. Ralstonia solanacearum requires type 4 pili to adhere to multiple surfaces and for natural transformation and virulence. Mol. Microbiol. 46:427-437.

Koenig, R. L., Ray, J. L., Maleki, S. J., Smeltzer, M. S., and Hurlburt, B. K. 2004. Staphylococcus aureus AgrA binding to the RNAIII-agr regulatory region. J. Bacteriol. 186:7549-7555.

Koo, J., Tammam, S., Ku, S. Y., Sampaleanu, L. M., Burrows, L. L., and Howell, P. L. 2008. PilF is an outer membrane lipoprotein required for multimerization and localization of the Pseudomonas aeruginosa Type IV pilus secretin. J. Bacteriol. 190:6961-6969.

Kovach, M. E., Elzer, P. H., Hill, D. S., Robertson, G. T., Farris, M. A., Roop, R. M., 2nd, and Peterson, K. M. 1995. Four new derivatives of the broad-host-range cloning vector $\mathrm{pBBR} 1 \mathrm{MCS}$, carrying different antibioticresistance cassettes. Gene 166:175-176.

Kraxenberger, T., Fried, L., Behr, S., and Jung, K. 2012. First insights into the unexplored two-component system YehU/YehT in Escherichia coli. J. Bacteriol. 194:4272-4284

Li, Y., Hao, G., Galvani, C. D., Meng, Y., De La Fuente, L., Hoch, H. C., and Burr, T. J. 2007. Type I and type IV pili of Xylella fastidiosa affect twitching motility, biofilm formation and cell-cell aggregation. Microbiology 153:719-726.

Lim, S. H., So, B. H., Wang, J. C., Song, E. S., Park, Y. J., Lee, B. M., and Kang, H. W. 2008. Functional analysis of pilQ gene in Xanthomonas oryzae pv. oryzae, bacterial blight pathogen of rice. J. Microbiol. 46:214-220.

Liu, H., Kang, Y., Genin, S., Schell, M. A., and Denny, T. P. 2001. Twitching motility of Ralstonia solanacearum requires a type IV pilus system. Microbiology 147:3215-3229.

Lizewski, S. E., Schurr, J. R., Jackson, D. W., Frisk, A., Carterson, A. J., and Schurr, M. J. 2004. Identification of AlgR-regulated genes in Pseudomonas aeruginosa by use of microarray analysis. J. Bacteriol. 186:5672-5684.

Makizumi, Y., Igarashi, M., Gotoh, K., Murao, K., Yamamoto, M., Udonsri, N., Ochiai, H., Thummabenjapone, P., and Kaku, H. 2011. Genetic diversity and pathogenicity of cucurbit-associated Acidovorax. J. Gen. Plant Pathol. 77:24-32.

Marrs, C. F., Ruehl, W. W., Schoolnik, G. K., and Falkow, S. 1988. Pilingene phase variation of Moraxella bovis is caused by an inversion of the pilin genes. J. Bacteriol. 170:3032-3039.

Mattick, J. S. 2002. Type IV pili and twitching motility. Annu. Rev. Microbiol. 56:289-314

McCarthy, Y., Ryan, R. P., O’Donovan, K., He, Y. Q., Jiang, B. L., Feng, J. X., Tang, J. L., and Dow, J. M. 2008. The role of PilZ domain proteins in the virulence of Xanthomonas campestris pv. campestris. Mol. Plant Pathol. 9:819-824.

Meng, Y., Li, Y., Galvani, C. D., Hao, G., Turner, J. N., Burr, T. J., and Hoch, H. C. 2005. Upstream migration of Xylella fastidiosa via pilusdriven twitching motility. J. Bacteriol. 187:5560-5567.

Nguyen, L. C., Taguchi, F., Tran, Q. M., Naito, K., Yamamoto, M., OhnishiKameyama, M., Ono, H., Yoshida, M., Chiku, K., Ishii, T., Inagaki, Y., Toyoda, K., Shiraishi, T., and Ichinose, Y. 2012. Type IV pilin is glycosylated in Pseudomonas syringae pv. tabaci 6605 and is required for surface motility and virulence. Mol. Plant Pathol. 13:764-774.

Nikolskaya, A. N., and Galperin, M. Y. 2002. A novel type of conserved DNA-binding domain in the transcriptional regulators of the AlgR/AgrA/LytR family. Nucleic Acids Res. 30:2453-2459.

Noinaj, N., Guillier, M., Barnard, T. J., and Buchanan, S. K. 2010. TonBdependent transporters: Regulation, structure, and function. Annu. Rev. Microbiol. 64:43-60.

Nudleman, E., and Kaiser, D. 2004. Pulling together with type IV pili. J. Mol. Microbiol. Biotechnol. 7:52-62.

O’Toole, G. A., Pratt, L. A., Watnick, P. I., Newman, D. K., Weaver, V. B., and Kolter, R. 1999. Genetic approaches to study of biofilms. Methods Enzymol. 310:91-109.
Okkotsu, Y., Little, A. S., and Schurr, M. J. 2014. The Pseudomonas aeruginosa AlgZR two-component system coordinates multiple phenotypes. Front. Cell. Infect. Microbiol. 4:82.

Postle, K., and Kadner, R. J. 2003. Touch and go: Tying TonB to transport. Mol. Microbiol. 49:869-882.

Rodriguez-Soto, J. P., and Kaiser, D. 1997. Identification and localization of the $\mathrm{Tgl}$ protein, which is required for Myxococcus xanthus social motility. J. Bacteriol. 179:4372-4381.

Sambrook, J., Fritsch, E. F., and Maniatis, T. 1989. Molecular Cloning: A Laboratory Manual. Cold Spring Harbor Laboratory Press, Cold Spring Harbor, NY, U.S.A.

Schaad, N. W., Postnikova, E., Sechler, A., Claflin, L. E., Vidaver, A. K., Jones, J. B., Agarkova, I., Ignatov, A., Dickstein, E., and Ramundo, B. A. 2008. Reclassification of subspecies of Acidovorax avenae as A. Avenae (Manns 1905) emend., A. cattleyae (Pavarino, 1911) comb. nov., A. citrulli Schaad et al., 1978) comb. nov., and proposal of A. oryzae sp. nov. Syst. Appl. Microbiol. 31:434-446.

Schauer, K., Rodionov, D. A., and de Reuse, H. 2008. New substrates for TonB-dependent transport: Do we only see the 'tip of the iceberg'? Trends Biochem. Sci. 33:330-338.

Segal, E., Billyard, E., So, M., Storzbach, S., and Meyer, T. F. 1985. Role of chromosomal rearrangement in $N$. gonorrhoeae pilus phase variation. Cell 40:293-300.

Shrestha, R. K., Rosenberg, T., Makarovsky, D., Eckshtain-Levi, N., Zelinger, E., Kopelowitz, J., Sikorski, J., and Burdman, S. 2013. Phenotypic variation in the plant pathogenic bacterium Acidovorax citrulli. PLoS One 8:e73189.

Simon, R., Priefer, U., and Puhler, A. 1983. A broad host range mobilization system for in vivo genetic engineering: Transposon mutagenesis in gram negative bacteria. Biotechnology 1:784-791.

Somodi, G. C., Jones, J. B., Hopkins, D. L., Stall, R. E., Kucharek, T. A. Hodge, N. C., and Watterson, J. C. 1991. Occurrence of a bacterial watermelon fruit blotch in Florida. Plant Dis. 75:1053-1056.

Takase, H., Nitanai, H., Hoshino, K., and Otani, T. 2000. Requirement of the Pseudomonas aeruginosa ton $B$ gene for high-affinity iron acquisition and infection. Infect. Immun. 68:4498-4504.

Vieira, J., and Messing, J. 1982. The pUC plasmids, an M13mp7-derived system for insertion mutagenesis and sequencing with synthetic universal primers. Gene 19:259-268.

Villar, M. T., Helber, J. T., Hood, B., Schaefer, M. R., and Hirschberg, R. L. 1999. Eikenella corrodens phase variation involves a posttranslational event in pilus formation. J. Bacteriol. 181:4154-4160.

Wadhams, G. H., and Armitage, J. P. 2004. Making sense of it all: Bacterial chemotaxis. Nat. Rev. Mol. Cell Biol. 5:1024-1037.

Walcott, R. R., Fessehaie, A., and Castro, A. C. 2004. Differences in pathogenicity between two genetically distinct groups of Acidovorax avenae subsp. citrulli on cucurbit hosts. J. Phytopathol. 152:277-285.

Walcott, R. R., Langston, D. B., Jr., Sanders, F. H., Jr., and Gitaitis, R. D. 2000. Investigating intraspecific variation of Acidovorax avenae subsp. citrulli using DNA fingerprinting and whole cell fatty acid analysis. Phytopathology 90:191-196.

Wall, G. C., and Santos, V. M. 1988. A new bacterial disease on watermelon in the Mariana Islands. Phytopathology 78:1605.

Wang, J. C., So, B. H., Kim, J. H., Park, Y. J., Lee, B. M., and Kang, H. W. 2008. Genome-wide identification of pathogenicity genes in Xanthomonas oryzae pv. oryzae by transposon mutagenesis. Plant Pathol. 57:1136-1145.

Watson, A. A., Alm, R. A., and Mattick, J. S. 1996. Identification of a gene, pilF, required for type 4 fimbrial biogenesis and twitching motility in Pseudomonas aeruginosa. Gene 180:49-56.

Whitchurch, C. B., Alm, R. A., and Mattick, J. S. 1996. The alginate regulator $\mathrm{AlgR}$ and an associated sensor FimS are required for twitching motility in Pseudomonas aeruginosa. Proc. Natl. Acad. Sci. U.S.A. 93:9839-9843.

Whitchurch, C. B., Leech, A. J., Young, M. D., Kennedy, D., Sargent, J. L., Bertrand, J. J., Semmler, A. B. T., Mellick, A. S., Martin, P. R., Alm, R. A., Hobbs, M., Beatson, S. A., Huang, B., Nguyen, L., Commolli, J. C., Engel, J. N., Darzins, A., and Mattick, J. S. 2004. Characterization of a complex chemosensory signal transduction system which controls twitching motility in Pseudomonas aeruginosa. Mol. Microbiol. 52: 873-893.

Zahavi, E. E., Lieberman, J. A., Donnenberg, M. S., Nitzan, M., Baruch, K. Rosenshine, I., Turner, J. R., Melamed-Book, N., Feinstein, N., ZlotkinRivkin, E., and Aroeti, B. 2011. Bundle-forming pilus retraction enhances enteropathogenic Escherichia coli infectivity. Mol. Biol. Cell 22:2436-2447.

\section{AUTHOR-RECOMMENDED INTERNET RESOURCE}

Restriction Free Cloning database: www.rf-cloning.org 